\title{
REPRODUCTIVE AND PHYSIOLOGICAL TRAITS OF OSSIMI RAMS AS AFFECTED BY VITAMIN E AND SELENIUM INJECTION
}

\author{
Gamal B. Mahmoud ${ }^{1}$, Sh. M. Abdel-Raheem ${ }^{2}$ and H. A. Hussein ${ }^{3}$
}

1-Department of Animal Production, Faculty of Agriculture, 2- Department of Nutrition and Clinical Nutrition, Faculty of Veterinary Medicine, 3- Department of Theriogenology, Faculty of Veterinary Medicine, ${ }^{1,2,3}$ Assiut University, 71526, Assiut, Egypt

\section{SUMMARY}

The objective of this study was to determine the changes in the reproductive and physiological traits of Egyptian Ossimi rams during and after injection of a combination of vitamin E and selenium (Se). Fourteen mature healthy Ossimi rams were randomly divided into two equal groups (7 rams per group). The first group served as control group (CG), while the $2^{\text {nd }}$ group served as a treatment group (TG). Rams of the TG were treated twice weekly with $5 \mathrm{mg}$ sodium selenite and $450 \mathrm{mg}$ vitamin E for one month. Testicular measurements for each ram were recorded every one week for one month during the treatment and one month after the treatment. Accessory glands and testes were examined by sonar (ultrasound technique) and semen was collected using an artificial vagina. Blood samples were collected from the jugular vein at 8.0 a.m. for measuring some biochemical parameters and measuring testosterone hormone.

The results of the current study revealed that, during the treatment period there were no significant differences $(P>0.05)$ between the treated and control groups in the ejaculation volume and mass motility. However, there were significant improvements in the total sperm concentration (3 fold higher), the percentage of live spermatozoa (15.7\% higher), total sperm abnormalities (13.7\% lower) and reaction time (1.8 fold) in treated rams in comparison with the controls. After the treatment period, all semen characteristics were significantly improved. Selenium and vitamin E had no significant impact on the testes dimensions during the treatment period and had little effect on testes dimensions and ultrasonography of the testes. There were numerical increases in all testes dimensions after treatment beside the significant increase in seminal gland. During the treatment period, rams injected with vitamin E plus Se had higher $(P<0.001)$ values for blood cholesterol (8.5\% higher) and calcium and lower values for serum alanine aminotransferase in comparison with the control group. However after the treatment period, rams of the TG group had higher serum total protein, albumen, globulin, glucose (2 fold higher), serum testosterone, cholesterol, calcium and lower values for serum alanine aminotransferase and Aspartate aminotransferase compared to control rams.

In conclusion, administration with the combination of Se and vitamin E induced profound positive changes in the reproductive and physiological traits of Ossimi rams and these changes appear after the fourth week of injection.

Keywords: Rams, selenium, vitamin E, testes, accessory glands, testosterone, semen characteristics, blood parameters

\section{INTRODUCTION}

Vitamins and minerals play an important role in the growth of animals and their reproductive performance. Vitamins play a key role in thermoregulation of rectal and scrotal skin temperature during heat stress and maintain libido, semen quality and fertility (El-Darawany, 1999). Selenium acts to help and prevent oxidation of the sperm cell, thus aiding in maintaining sperm cell integrity (Cohen and Takasaki, 1986; Zhang et al., 1989; and Chu et al., 1996). Selenium represents an integral component of glutathione peroxidase (GSH$\mathrm{Px}$ ), an enzyme which, along with vitamin E, protects cell internal structures against free radicals and is an antioxidant for cellular membrane lipids (Ursini et al., 1999). Selenium deficiency has been linked to reproductive problems in sheep and cattle (Combs and Combs, 1986) and leads to largely immotile and a high incidence of sperm midpiece defects. In males bred on a low selenium diet, male hypogonadism was found as well as reduced production and deteriorated semen quality (Peretz et al., 1991 and Kleene, 1993) and supplementation with selenium has been reported to improve reproductive performance in sheep. It was demonstrated that a diet supplemented with selenium and vitamin $\mathrm{E}$ improved sperm quality an effect possibly linked to the antioxidant properties of this vitamin (Brzezinska-Slebodzinska et al., 1995 and Marin-Guzman et al., 1997).Vitamin E and selenium are essential nutrients with complementary biological functions as antioxidants for minimizing cellular damage caused by endogenous peroxides (Kolb et al., 1997). Vitamin E prevents oxidative damage to sensitive membrane lipids by suppressing hydro peroxide formation (Chow, 2001) and protects cellular membranes thus maintaining membrane integrity and reducing oxidative stress (Hogan et al., 1993). There is physiological synergism between selenium and vitamin E. Previous reports have suggested that vitamin $\mathrm{E}$ and selenium (Se) are important nutrients that act synergistically and can affect many biological processes including spermatogenesis and semen quality (Marin- Guzman et al., 1997; and Yousef et al., 2003), reproduction (Jerry, 1996; and Koyuncu and Yerlikaya, 2007), metabolism (Awadeh et al., 1998), immunity (Hernken et al., 1998), and protecting against oxidative stress (Bernabucci et al., 2002). The association of vitamin E deficiency with impaired 
male reproduction was established more than three decades ago, and traditionally it is called the "antisterility vitamin". Therefore, the aim of the present study was to evaluate the effect of the combination of vitamin $\mathrm{E}$ and $\mathrm{Se}$ injection on reproductive performance of Ossimi rams and on some biochemical and physiological parameters.

\section{MATERIALS AND METHODS}

\section{Animals and experimental design:}

The present study was carried out in the Experimental Farm of Animal Production Department, Faculty of Agriculture, Assiut University, Egypt. This study was conducted during May and June, 2011. Rams were kept in semi open pens under the normal environmental conditions. A total number of fourteen sexually mature Ossimi rams healthy and clinically free from external and internal parasites were used. The rams were aged between 1.5 and 2 years and averaged $46.6 \pm 1.4 \mathrm{~kg}$ body weight. Rams were randomly divided into two equal groups (7 per group). The first group with no supplementation was considered as a control group (CG); the second group served as a treated group (TG). The rams belonging to the TG were injected with a combination of selenium and vitamin $E[3 \mathrm{ml}$ IM from Viteselen $15^{\circledR}$, Adwia Company, Egypt]. Each ram from the TG was injected with $5 \mathrm{mg}$ sodium selenite and $450 \mathrm{mg}$ vitamin E two times / week for one month. All rams were fed the experimental diet which was formulated according to the requirement for mature ram according to NRC (1985) for sheep. Ration contained $2.33 \mathrm{Mcal} / \mathrm{kg}$ metabolizable energy, $13.66 \%$ crude protein, $1.97 \%$ crude fat, $11.3 \%$ crude fiber, $1.2 \%$ Limestone, $0.51 \%$ calcium and $0.3 \%$ phosphorus. The experimental diet for both groups contained $0.1 \mathrm{ppm}$ Se and $15 \mathrm{mg}$ vitamin E / kg. Rations were prepared weekly and animals had a free access to water all day.

\section{Semen collection and analysis:}

Observation of the sexual behavior for each ram was carried out daily between 8:00 a.m. to 9:00 a.m. Libido was evaluated by introducing rams to a teaser ewe selected as random. All ram lambs were allowed to go out to the collection area without restraint to observe the sexual activity toward the ewe. Rams, which achieved erection and extrusion of the penis out of the sheath, were trained for semen collection using an artificial vagina. Rams were allowed one false mount before semen collection and semen was collected during the subsequent mounting. Semen was collected one month during the treatment and one month after the treatment.

Two ejaculates per week were collected from each ram using an artificial vagina. Semen was evaluated immediately upon collection for general characters (volume, concentration, $\mathrm{pH}$, mass movement, live, dead sperm and abnormal spermatozoa). Semen volume (ml) was measured using a graduated collection tube to the nearest 0.1 $\mathrm{ml}$. Initial $\mathrm{pH}$ of semen samples was measured by means of comparative nitrating $\mathrm{pH}$ paper. Mass movement of sperm was assessed at a low magnification (x10), scored on a scale from 0 (no motility) to 5 (excellent motility). The percentages of live and dead sperms were determined from fixedsmear stained with eosin. Two hundred sperms were calculated from different fields in the stained smear, the colored head sperm was calculated as a dead sperm, while a colorless sperm was considered as a live sperm. Sperms abnormalities were classified into two categories according to (Blom, 1959). Defects which occur during spermatogenesis were considered a primary and those developing subsequent to spermiation considered as secondary. Sperm concentration was determined by the use of the Haemocytometer. Total number of spermatozoa per ejaculate was calculated by multiplying the ejaculate volume x sperm concentration per ml. Reaction time for each ram was recorded as the time needed for mounting an ewe until complete ejaculation. It was measured in seconds using stopwatch.

\section{Scrotal and testes measurements:}

Scrotal circumference was measured by using a steel tape (Ahmad and Noakes, 1995). The length and the width of the testes were measured using a pair of metal calipers (Islam and Land, 1977). Testis length was measured from top of the tail to the head of the epididymis for each testis. The width of the testis was measured between the lateral surface of the testis and scrotal raphi.

\section{Ultrasonographic (sonar) examinations:}

The testes and accessory genital glands including seminal, prostate and bulbouretheral glands were scanned per rectum using ultrasound scanner with $6 / 8 \mathrm{MHz}$ linear array transrectal probe (Pie Medical 100 LC, Holland) once weekly for eight weeks (one month during and one month after treatment). The transducer was fitted in a self- manufactured connector to favor its manipulation per rectum. All examinations were done by the same operator.

\section{Blood sampling and analysis:}

Blood samples were collected from the jugular vein at 8.00 a.m. before watering and feeding for determination of some biochemical parameters and testosterone hormone. Blood samples were allowed to clot at $4^{\circ} \mathrm{C}$ for 10 hours in the refrigerator, then were centrifuged and harvested sera were stored at $20^{\circ} \mathrm{C}$ until subsequent analysis. Blood parameters (total protein, albumen, glucose, cholesterol, AST (Aspartate aminotransferase), ALT (Alanine aminotransferase), $\mathrm{Ca}$ and $\mathrm{P}$ ) analyses were carried out by spectrophotometer using commercial test kits (Spinreact, Spain). Globulin values and Albumen/globulin (A/G) were calculated ratio. Serum testosterone concentration was determined using ELISA kits (Bio Check, Foster City, CA 94404, USA) using the micro-well method. The standard calibration curve was performed fore samples at $450 \mathrm{~nm}$ optical density using standards ranging from 0 to $18.0 \mathrm{ng} / \mathrm{ml}$. The kit had a sensitivity value of $0.05 \mathrm{ng} / \mathrm{ml}$ with the inter- and intra-assay coefficient of variations of 3.7 and $5.0 \%$, respectively. 


\section{Statistical analysis:}

Statistical analysis was performed using SPSS for Windows version 16.0 (SPSS, 2007). Comparison between groups was made by independent $t$-test. The Kolmogorov-Smirnov test was used to test the normal distribution of the data. Results are presented as means \pm standard errors of means (SEM).Values of $\mathrm{P}<0.05$ were considered significant.

\section{RESULTS AND DISCUSSION}

During the treatment period, there were no significant differences $(\mathrm{P}>0.05)$ between $\mathrm{TG}$ and $\mathrm{CG}$ with respect to ejaculate volume and mass motility as shown in Table 1 . However, there were significant improvements in the total sperm concentration (3 fold higher), the percentage of live spermatozoa (15.7\% higher), total abnormalities (13.7\% lower) and reaction time (1.8 fold lower) in treated ram in comparison with the control one. In addition, after treatment, there were significant $(\mathrm{P}<0.001)$ increases in the ejaculate volume (37.5\% higher), mass motility (22.8\% higher), total sperm concentration (2.8 fold), the percentage of live spermatozoa (14.7 $\%$ higher) in treated rams. At the same time, there were significant decreases in the reaction time (93.4 $\%$ ) and abnormal spermatozoa ( 2 fold) in the treated rams compared with control one (Table 1). These results are in agreement with those reported by Yousef et al. (2003); Kolodztiej and Jacyno (2005); Balicka-Ramisz et al. (2006); Ali et al. (2009); Marai et al. (2009). Improvement of semen quality is due to the improvement of testes function (Underwood, 1977). Selenium affects the interstitial cells of testes directly and via the effect on the anterior pituitary hormones secretion indirectly (Yousef et al., 1990). In contrast, Bearden and Fuquay (1997) showed that treatment with vitamin $\mathrm{E}$ and Se leads to an increased testosterone level that has a direct effect on secondary sexual activity. Moreover, Se is necessary for the development of germ cells in testes during development of spermatozoa and has positive effects on the number of germ cells in adults (Liu et al., 1982). Furthermore, Se seems to be essential for Sertoli cell development and ultimately the number of Sertoli cells in the developing testes. This effect becomes more pronounced as animals become older, suggesting that $\mathrm{Se}$ is important during testicular development (Marin-Guzman et al., 2000).
Brezinska-Slebodinska et al. (1995) observed that supplementation with vitamin $\mathrm{E}$ increased the concentration of spermatozoa in semen. This may be related to the effect of vitamin $\mathrm{E}$ and $\mathrm{Se}$ on sperm metabolism and conformation (Marin- Guzman et al., 1997), as sperm motility increased in selenium treated groups. Contrary to our findings, other authors have reported that the addition of inorganic Se to the diets of rams, boars, and dairy or beef bulls did not improve their semen quality (Audit et al., 2004). This discrepancy may be related to differences among species or treatments. Dietary deficiencies of vitamin $\mathrm{E}$ in growing males causes degenerative spermatogonium (Mason, 1954), resulting in a lower sperm concentration (Cooper et al., 1987). Vitamin E (Hope et al., 1975) and Se (Doni et al., 1981) have both been found to affect prostaglandin F2 $\alpha$ (PGF2 $\alpha$ ) production. Prostaglandin F2 $\alpha$ administration has increased the number and motility of spermatozoa in bulls, rabbits and stallions (Marshall and Hafs, 1976). Furthermore, positive effect of selenium on sperm concentration and morphology has been previously confirmed (Heimann et al., 1984; Behne et al., 1996 and MarinGuzman et al., 2000). The significantly $(\mathrm{P}<0.001)$ higher libido, semen ejaculate volume, sperm-cell concentration, total concentration of sperms and higher percentages of live spermatozoa in treated rams could be due to high testosterone level in the serum. It is known that there is a positive correlation between testosterone concentration and sexual activity in males. Under the conditions of our experiment, sexual activity increased after treatment with vitamin $E$ in combination with Se. This increase in sexual activity combined with increased testosterone concentration leads to a direct effect on semen volume. Kaur and Bansal (2004) demonstrated that the levels of testosterone, FSH, LH were significantly reduced during Se deficiency, which has been implicated in testicular dysfunction.

The significant reduction in the reaction time in treated rams is in accordance with the finding of Ali et al. (2009) and Marai et al. (2009). In contrast, testosterone is in part responsible for the mating behaviour or libido in rams. As testosterone production increases, the ram will generally become more sexually active than inactive or a sexual ram (Stellflug et al., 2004).

Table 1. Effects of vitamin $E$ and selenium (Se) injection (Mean \pm SEM) on semen traits of control (CG) and treated (TG) groups of Ossimi rams.

\begin{tabular}{|c|c|c|c|c|c|c|}
\hline \multirow{2}{*}{ Item } & \multicolumn{3}{|c|}{ During treatment } & \multicolumn{3}{|c|}{ After treatment } \\
\hline & $\mathrm{CG}$ & TG & $\mathrm{P} \leq$ & $\mathrm{CG}$ & TG & $\mathrm{P} \leq$ \\
\hline Ejaculate volume (ml) & $0.8 \pm 0.1$ & $1.0 \pm 0.0$ & 0.47 & $0.8 \pm 0.0^{\mathrm{a}}$ & $1.1 \pm 0.0^{b}$ & 0.01 \\
\hline $\mathrm{pH}$ & $6.7 \pm 0.0^{\mathrm{b}}$ & $6.9 \pm 0.1^{\mathrm{a}}$ & 0.01 & $7.0 \pm 0.0^{\mathrm{a}}$ & $6.7 \pm 0.0^{\mathrm{b}}$ & 0.001 \\
\hline Mass motility & $2.9 \pm 0.4$ & $3.6 \pm 0.3$ & 0.25 & $3.5 \pm 0.2^{\mathrm{b}}$ & $4.3 \pm 0.3^{\mathrm{a}}$ & 0.01 \\
\hline Sperm concentration/ml $\left(\mathrm{X} 10^{9}\right)$ & $1.2 \pm 0.1^{\mathrm{b}}$ & $2.4 \pm 0.01^{\mathrm{a}}$ & 0.001 & $1.8 \pm 0.1^{b}$ & $3.5 \pm 0.2^{\mathrm{a}}$ & 0.001 \\
\hline Total sperm / ejaculate $\left(\mathrm{X} 10^{9}\right)$ & $0.7 \pm 0.2^{\mathrm{b}}$ & $2.1 \pm 0.3^{\mathrm{a}}$ & 0.001 & $1.3 \pm 0.1^{\mathrm{b}}$ & $3.6 \pm 0.2^{\mathrm{a}}$ & 0.001 \\
\hline Live spermatozoa $(\%)$ & $48.6 \pm 4.6^{\mathrm{b}}$ & $64.3 \pm 2.7^{\mathrm{a}}$ & 0.01 & $61.6 \pm 2.3^{b}$ & $76.3 \pm 2.5^{\mathrm{a}}$ & 0.001 \\
\hline Dead spermatozoa (\%) & $51.4 \pm 4.4^{\mathrm{a}}$ & $35.7 \pm 2.7^{b}$ & 0.01 & $38.4 \pm 2.3^{\mathrm{a}}$ & $23.6 \pm 2.5^{\mathrm{a}}$ & 0.001 \\
\hline Total abnormal (\%) & $36.4 \pm 3.2^{\mathrm{a}}$ & $22.7 \pm 1.6^{\mathrm{b}}$ & 0.001 & $33.9 \pm 2.2^{\mathrm{a}}$ & $17.1 \pm 1.9^{b}$ & 0.001 \\
\hline Reaction time $(\mathrm{S})$ & $58.1 \pm 9.5^{\mathrm{a}}$ & $32.2 \pm 4.7^{\mathrm{b}}$ & 0.03 & $37.9 \pm 1.3^{\mathrm{a}}$ & $2.5 \pm 0.3^{b}$ & 0.01 \\
\hline
\end{tabular}

$\mathrm{a}$ and $\mathrm{b}$ Means within the same row with different superscripts are significantly different. 
Vitamin E and selenium had no significant impact on the testes dimensions and ultrasonography of the testes during the treatment period (Table 2). There were numerical increases in all testes dimensions after treatment. The numerical increase in ordinary testes measurements (Table 2) including the right and left testes diameters, length, epididymis and scrotal circumferences beside the significant increase in some sonar parameters of the testes and accessory genital glands reflect the positive correlation between testes measurement and semen quality. It has been reported that there was a close relationship between testicular size and sperm production. Rams with small testes may not produce enough sperm through the joining period to maintain good fertilization rates (Mahmoud, 2002). Testes size is often used as a judge of fertility and scrotal measurement is used as a basis for choosing breeding ram (Toe et al., 2000).

Table 2. Testes and accessory genital glands measurements (Mean \pm SEM) of control (CG) and treated (TG) rams with vitamin $\mathrm{E}$ and selenium (Se) injection.

\begin{tabular}{|c|c|c|c|c|}
\hline \multirow{2}{*}{ Item } & \multicolumn{2}{|c|}{ During treatment } & \multicolumn{2}{|c|}{ After treatment } \\
\hline & CG & $\mathrm{TG}$ & $\mathrm{CG}$ & $\mathrm{TG}$ \\
\hline \multicolumn{5}{|l|}{ Caliper measurement $(\mathrm{cm})$} \\
\hline Scrotal circumference & $28.2 \pm 0.9$ & $29.6 \pm 0.9$ & $28.3 \pm 1.6$ & $29.7 \pm 0.6$ \\
\hline Right testis length & $9.1 \pm 0.3$ & $9.1 \pm 0.4$ & $9.2 \pm 0.5$ & $9.7 \pm 0.3$ \\
\hline Right testis width & $5.1 \pm 0.2$ & $5.1 \pm 0.3$ & $5.1 \pm 0.2$ & $5.3 \pm 0.2$ \\
\hline Right epididymis & $2.4 \pm 0.1$ & $2.5 \pm 0.1$ & $2.6 \pm 0.1$ & $2.7 \pm 0.1$ \\
\hline Left testis length & $8.9 \pm 0.4$ & $8.9 \pm 0.3$ & $8.8 \pm 0.6$ & $9.5 \pm 0.3$ \\
\hline Left testis width & $4.6 \pm 0.2$ & $4.9 \pm 0.2$ & $4.8 \pm 0.2$ & $5.0 \pm 0.2$ \\
\hline Left epididymis & $2.4 \pm 0.1$ & $2.6 \pm 0.1$ & $2.7 \pm 0.1$ & $3.0 \pm 1.4$ \\
\hline \multicolumn{5}{|l|}{ Ultrasonography (cm) } \\
\hline Right testis width & $4.4 \pm 0.2$ & $4.6 \pm 0.3$ & $5.1 \pm 0.3$ & $5.7 \pm 0.2$ \\
\hline Left testis width & $4.3 \pm 0.2$ & $4.9 \pm 0.2$ & $5.3 \pm 0.2$ & $5.5 \pm 0.1$ \\
\hline Right seminal gland & $1.2 \pm 0.1$ & $1.3 \pm 0.1$ & $1.3 \pm 0.0^{\mathrm{b}}$ & $1.6 \pm 0.0^{\mathrm{a}}$ \\
\hline Left seminal gland & $1.2 \pm 0.1$ & $1.3 \pm 0.1$ & $1.3 \pm 0.1^{\mathrm{b}}$ & $1.5 \pm 0.0^{\mathrm{a}}$ \\
\hline Right bulbouretheral gland & $1.0 \pm 0.0$ & $1.1 \pm 0.0$ & $1.0 \pm 0.0$ & $1.1 \pm 0.0$ \\
\hline Left bulbouretheral gland & $0.9 \pm 0.0$ & $1.1 \pm 0.0$ & $0.9 \pm 0.0$ & $1.1 \pm 0.0$ \\
\hline Prostate gland & $0.8 \pm 0.1$ & $0.9 \pm 0.1$ & $0.8 \pm 0.0$ & $0.9 \pm 0.0$ \\
\hline
\end{tabular}

${ }^{\mathrm{a} a n d b}$ Means within the same row with different superscripts are significantly different $(\mathrm{P}<0.05)$.

During the treatment period, rams injected with vitamin $\mathrm{E}$ plus $\mathrm{Se}$ showed higher $(\mathrm{P}<0.001)$ values for blood cholesterol (8.5\% higher) and calcium only and lower values for serum ALT in comparison with the control group (Table 3). However after treatment period, rams treated with vitamin $\mathrm{E}$ and $\mathrm{Se}$ had higher serum total protein, albumen, globulin, glucose (two fold), serum testosterone, cholesterol, calcium compared to control rams (Table 3). These results agree with the finding of Balicka-Ramisz et al. (2006). This may be due to improvement of protein anabolism and decreased protein catabolism. In addition, the increase in the other blood metabolites could be ascribed to the improved feed efficiency by vitamin $\mathrm{E}$ and the improvement in the overall animal health and/or reproductive performance. The significant increases in serum testosterone in treated rams are inconsistent with results of Marin-Guzman et al. (1997 and 2000). Another study showed that treatment with vitamin E and Se leads to increase testosterone level that has a direct effect on secondary sexual activity (Bearden and Fuquay, 1997). This increase in sexual activity combined with increased testosterone concentration leads to a direct effect on semen volume. Kaur and Bansal (2004) demonstrated that the levels of testosterone, FSH, LH were significantly reduced during Se deficiency.

Table 3. Effects of vitamin $\mathbf{E}$ and selenium (Se) injection on blood parameters of control (CG) and treated (TG) groups of Ossimi rams (Mean \pm SEM)

\begin{tabular}{|c|c|c|c|c|c|c|}
\hline \multirow{2}{*}{ Item } & \multicolumn{3}{|c|}{ During treatment } & \multicolumn{3}{|c|}{ After treatment } \\
\hline & $\mathrm{CG}$ & TG & $\mathrm{P} \leq$ & $\mathrm{CG}$ & TG & $\mathrm{P} \leq$ \\
\hline Total protein $(\mathrm{g} / \mathrm{dl})$ & $6.1 \pm 0.2$ & $6.5 \pm 0.2$ & $\mathrm{~ns}$ & $7.1 \pm 0.1^{b}$ & $7.8 \pm 0.0^{\mathrm{a}}$ & 0.001 \\
\hline Albumen $(\mathrm{g} / \mathrm{dl})$ & $3.7 \pm 0.1$ & $3.9 \pm 0.1$ & ns & $3.9 \pm 0.1^{\mathrm{b}}$ & $4.2 \pm 0.1^{\mathrm{a}}$ & 0.01 \\
\hline Globulin(g/dl) & $2.5 \pm 0.1$ & $2.7 \pm 0.2$ & ns & $3.2 \pm 0.1^{\mathrm{b}}$ & $3.6 \pm 0.1^{\mathrm{a}}$ & 0.01 \\
\hline $\mathrm{A} / \mathrm{G}$ ratio & $1.4 \pm 0.1$ & $1.5 \pm 0.1$ & ns & $1.1 \pm 0.1$ & $1.2 \pm 0.1$ & ns \\
\hline Glucose (mg/ dl) & $86.8 \pm 1.5$ & $87.9 \pm 1.2$ & ns & $44.8 \pm 2.2^{b}$ & $88.1 \pm 1.3^{\mathrm{a}}$ & 0.01 \\
\hline Cholesterol (mg/ dl) & $68.9 \pm 0.9^{b}$ & $74.8 \pm 1.2^{\mathrm{a}}$ & 0.001 & $67.8 \pm 1.2^{\mathrm{b}}$ & $76.7 \pm 1.3^{\mathrm{a}}$ & 0.001 \\
\hline $\operatorname{AST}(\mathrm{U} / \mathrm{l})$ & $75.5 \pm 0.6$ & $76.3 \pm 0.5$ & ns & $82.1 \pm 0.9^{\mathrm{a}}$ & $72.9 \pm 1.3^{\mathrm{b}}$ & 0.001 \\
\hline ALT(U/l) & $44.1 \pm 2.0^{\mathrm{a}}$ & $36.3 \pm 1.0^{\mathrm{b}}$ & 0.01 & $51.1 \pm 1.1^{\mathrm{a}}$ & $42.3 \pm 1.0^{\mathrm{b}}$ & 0.001 \\
\hline Calcium (mg/ dl) & $11.5 \pm 0.0^{b}$ & $11.7 \pm 0.0^{\mathrm{a}}$ & 0.05 & $11.6 \pm 0.0$ & $11.8 \pm 0.1$ & 0.05 \\
\hline Phosphorus (mg/ dl) & $5.6 \pm 0.1$ & $5.6 \pm 0.1$ & ns & $5.7 \pm 0.1$ & $5.8 \pm 0.1$ & ns \\
\hline Testosterone (ng/ml) & $0.9 \pm 0.1$ & $1.2 \pm 0.1$ & ns & $1.0 \pm 0.1^{\mathrm{b}}$ & $1.3 \pm 0.1^{\mathrm{a}}$ & 0.05 \\
\hline
\end{tabular}


In conclusion, this study has demonstrated a clear positive effect of vitamin $\mathrm{E}$ and Se injection on semen characteristics, testes and accessory glands measurements and blood metabolites in Ossimi rams. Thus, this method of administration or injection especially during the breeding season could be employed in improving the reproductive performance of Ossimi rams in Egypt.

\section{REFERENCES}

Ahmad, N. and D. E. Noakes, 1995. Seasonal variation in testes size, libido and plasma testosterone concentration in British goats. Journal of Animal Scince, 61: 553-559.

Ali, A. B., G. Bomboi and B. Floris, 2009. Does vitamin $\mathrm{E}$ or vitamin $\mathrm{E}$ plus selenium improve reproductive performance of rams during hot weather. Italian Journal of Animal Science, 8: 743-754.

Audit, I., J.P. Laforst, G.P. Martineau and J.J. Matte, 2004. Effect of vitamin supplements on some aspects of performance, vitamin status, and semen quality in boars. Journal of Animal Science, 82:626-633.

Awadeh, F.T., M.M. Abdelrahman, R.L. Kincaid and J.W. Finley, 1998. Effect of selenium supplements on distribution of selenium among serum proteins in cattle. Journal of Dairy Science, 81:1089-1094.

Balicka-Ramisz, A, B Pilarczyk, A. Ramisz and M. Wiecorek, 2006. Effects of selenium administration on blood serum Se content and on selected reproductive characteristics of sheep. Arch Tierz, 49: 176-80

Bearden, H.J. and J.W. Fuquay, 1997. Applied Animal Reproduction. 4th ed. Pentice Hall, Upper Saddle, River, NJ, USA.

Behne, D., H. Weiler, and A. Kyriakopoulos, 1996. Effects of selenium deficiency on testicular morphology and function in rats. Journal of Reproduction and Fertility, 106: 291-297.

Bernabucci, U., B. Ronchi, N. Lacetera, and A. Nardone, 2002. Markers of oxidative status in plasma and erythrocytes of transition dairy cows during hot season. Journal of Dairy Science, 85:2173-2179.

Blom, E.,1959. Interpretation of spermatic cytology of bulls. Fertility and Sterility, 1:223-38

Brzezinska- Slebodzinska, E., A.B. Slebodzinska, B. Pietras and G. Wieczorek, 1995. Antioxidant effect of vitamin $\mathrm{E}$ and glutathione on lipid peroxidation in boor semen plasma. Biological Trace Element Research, 47:69-74.

Chow, C.K., 2001. In: R. Rucker, D.B. Suttle, McComick, L. Machlin and J. Editors (eds.), Handbook of vitamins. Marceldekker, New York, pp: 165-196.

Chu, F.F., H.A.R. DeSilva, R.S. Esworthy, K.K. Boteva, C.E. Walters, A. Roses, P.N. Rao, and M.J. Pettenati, 1996. Polymorphism and chromosomal localization of the GI-form of human glutathione peroxidase (GPX2) on $14 \mathrm{q} 24.1$ by in situ hybridization. Genomics, 32: 272-276.

Cohen, H.J. and K. Takahashi, 1986. Human plasma glutathione peroxidase isolation and characterization of a unique selenium enzyme. In: Proceedings of the $78^{\text {th }}$ Annual National Meeting of the American Society for Clinical Investigation. Washington, DC., USA.

Combs, G.F. and S.B. Combs, 1986. The Role of Selenium in Nutrition. Academic Press, San Diego.

Cooper, D.R., O. R.King and M. P. Carpenter, 1987. Effect of vitamin E deficiency on serum concentrations of follicle-stimulating hormone and testosterone during testicular maturation and degeneration. Endocrinology, 120:83-90.

Doni, M. G., G. L. Avvent, L. Bonadiman, and G. Bonaccorso, 1981. Glutathione peroxidase, selenium and prostaglandin synthesis in platelets. American Journal of Physiology, 240:H800-803.

El-Darawany, A.A., 1999. Improving semen quality of heat stressed rams in Egypt. Indian Journal of Animal Science, 69:1020-1023.

Heimann, E. D., M. F. Smith, J.S. Morris, T.J. Gall, R.G. Elmore and R.E. Morrow, 1984. Relationships among spermatozoal abnormalities and the selenium concentration of blood plasma, semen, and reproductive tissues in young bulls. Animal Reproduction Science, 7: 315-321.

Hernken, R.W., R.J. Harmon and S. Tramsmel, 1998. Selenium of dairy cattle: A role for organic selenium. In: T.P. Lyons and K.A. Jacques (eds.). Biotechnology in feed industry. Proceedings Alltech 14th Ann. Symp. Nottingham University Press, Loughborough, LEC, UK, pp. 797-803.

Hogan, J.S., W.P. Weiss and K.L. Smith, 1993. Role of vitamin $\mathrm{E}$ and selenium in host defense against mastitis. Journal of Dairy Science, 76:2795-2803.

Hope, W.C., C. Dalton, L.J. Machlin, R.J. Filipski and F.M. Vane, 1975. Influence of dietary vitamin $\mathrm{E}$ on prostaglandin biosynthesis in rat blood. Prostaglandins, 10: 557-571.

Islam, A.B.M. and R.B.C. Land, 1977. Seasonal variations in testes diameter and sperm output of rams of breeds of different prolificacy. Animal Production, 25: 311-317.

Jerry, D.O., 1996. The role of selenium and Vitamin. $\mathrm{E}$ in mastitis and reproduction of dairy cattle. Irish Veterinary Journal, 49:362-364.

Kaur, P. and M.P. Bansal, 2004. Effect of experimental oxidative stress on steriodogenesis and DNA damage in mouse testis. Journal of Biomedical Science, 11:391- 397.

Kleene, K.C., 1993. The Mitochondrial capsule selenoprotein - A Structural protein in the mitochondrial capsule of mammalian sperm, in: Selenium in Biology and Human Health, eds. R.F. Burk, Springer-Verlag, New York, 7:135-149.

Kolb, E., S. KasKousb and J. Scchawer, 1997. Nutrional aspects of the importance, utilization, metabolism and the use of vitamin $E$ and 
selenium in sheep. Berl Munch Tierarztl Wochenschr, 110:178-184.

Kolodztiej, A. and Jacyno E., 2005. Effect of selenium and vitamin $\mathrm{E}$ supplementation on reproductive performance of young boars. Arch Tierz, 48: 68-75.

Koyuncu, M. and H. Yerlikaya, 2007. Effect of selenium- vitamin $\mathrm{E}$ injections of ewes on reproduction and growth of their lambs. South African Journal of Animal Science, 37:233-236.

Liu, C.H., Y.M. Chen, J.Z. Zhang, M.Y. Huang, Q. Su, Z.H. Lu, R.X. Yin, G.Z. Shao, D. Feng and P.L. Zheng, 1982. Preliminary studies on influence of selenium deficiency to the developments of genital organs and spermatogenesis of infancy boars. Acta Veterinaria Zootech. Sin, 13:73-77.

Mahmoud, G.B.A., 2002. Some reproductive characteristics in saidi ram lambs as affected by feeding different levels of energy and protein. M.Sc. Thesis, Faculty of Agriculture, Assiut University, Assiut, Egypt.

Marai, I.F.M., A. El-Darawany, E.A. Ismail, and M.A.M. Abdel-Hafez, 2009. Reproductive and physiological traits of Egyptian Suffolk rams as affected by selenium dietary supplementation and housing heat radiation effects during winter of the sub-tropical environment of Egypt (Short Communication). Archiv Tierzucht, 52: 402-409.

Marin-Guzman, J., D. C. Mahan, and R. Whitmoyer. 2000. Effect of dietary selenium and vitamin $\mathrm{E}$ on the ultrastructure and ATP concentration of boar spermatozoa, and the efficacy of added sodium selenite in extended semen on sperm motility. Journal of Animal Science, 78:1544-1550.

Marin-Guzman, J., D. C. Mahan, Y. K. Chung, J. L. Pate, and W. F. Pope. 1997. Effects of dietary selenium and vitamin $\mathrm{E}$ on boar performance and tissue responses, semen quality, and subsequent fertilization rates in mature gilts. Journal of Animal Science, 75:2994-3003.

Marshall, C. E., and H. D. Hafs, 1976. Sperm output and quality after PGF $2 \alpha$ in bulls. Journal of Animal Science, 43:296 (Abstr.).

Mason, K. E., 1954. The tocopherols: Effects of deficiency. In: W. H. Sebrell and R. S. Harris (Eds.). The Vitamins, Academic Press, New York, USA, 3:514-572.
NRC, National Research Council, 1985. Nutrient Requirements of Sheep. $6^{\text {th }}$ ed National Academy Press, Washington DC, USA.

Peretz, A., J. Neve, J. Duchateau, V. Siderova, K. Huygen, J.P. Famaey and Y.A. Carpentier, 1991. Effects of selenium supplementation on immune parameters in gut failure patients on home parenteral nutrition. Nutrition, 7:215-221.

SPSS, 2007. Statistical package for the Social Sciences Version 13. Inc., Chicago, IL.

Stellflug, J.N., A. Perkins and V.A. LaVoie, 2004. Testosterone and luteinizing hormone responses to naloxone help predict sexual performance in rams. Journal of Animal Science, 82, 3380-3387.

Toe, F., J.E. Rege, E. Mukasa-Mugerwa, S. Tembely, D. Anindo, R.L. Baker and A. Lahlou-Kassi, 2000. Reproductive characteristics of Ethiopian highland sheep. I. Genetic paramseters of testicular measurements in ram lambs. Tropical Animal Health and Production, 39: 229-235.

Underwood, E.J., 1977. Trace Elements in Human and Animal Nutrition. $3^{\text {rd }}$ ed. New York, USA

Ursini, F., S. Heim, M. Kiess, M. Maiorino, A. Roveri, J. Wissing, and L. Flohe, 1999. Dual function of the selenoprotein PHGPx during sperm maturation. Science, 285:1393-1396.

Yousef, H.M., A. Abul-Ela, E.R. Farag, Y.L. Awad, F.E. El-Keraby and H.A. Hassanin, 1990. Effect of pre-partum selenium injection on reproductive and lactational performance and post-partum hormone profile in dairy cows. In: Proceedings of 4th Scientific Congress, Faculty of Veterinary Medicine, Assiut University. Assiut Egypt, PP. 445-54.

Yousef, M.I., G.A. Abdallah, and K.I. Kamel, 2003. Effect of ascorbic acid and vitamin $\mathrm{E}$ supplementation on semen quality and biochemical parameters of male rabbits. Animal Reproduction Science, 76:99-111.

Zhang, L., M. Maiorino, A. Roveri, and F. Ursini, 1989. Phospholipids hydro peroxide glutathione peroxidase specific activity in tissues of rats of different age and comparison with other glutathione peroxidase. Biochimica et Biophysica Acta, 1006:140-149. 
تأثثير الحقن بفيتامين هـ والسيلينيوم على الصفات التناسلية والفسيولجية للكباث الأوسيمي

جمال بلرى محمود1، شريف محمد عبد الرحيم²، حسن عبد الصبور على حسين3

1- قسم الإتتاج الحيواني، كلية الزراعة، 2- قسم التغنية، كلية الطب البيطرى، 3ـ قسم التوليد والتناسليات والتلقيح الأصطناعى كلية الطب البيطرى 1،2،3- جامعة أسيوط، أسيوط، مصر. 1اعر.

أجريت هذه الدراسة على أربعة عشر من ذكور الأغنام الأوسيمى بهذف دراسة التغيرات الفسيولجية والتناسلية لهذه الذكور أثناء وبعد الحقن

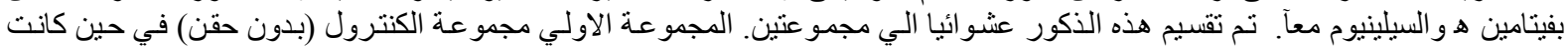

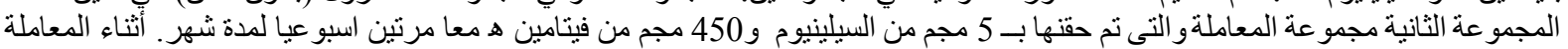

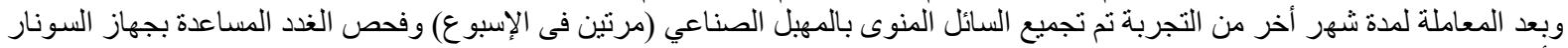
وأخذ عينة دم من كل ذكر (مرة كل إسبوع).

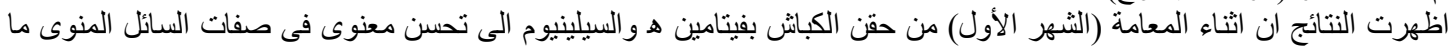

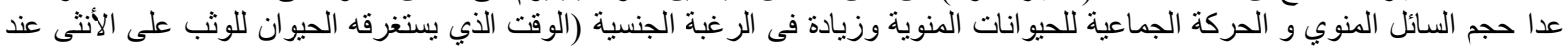

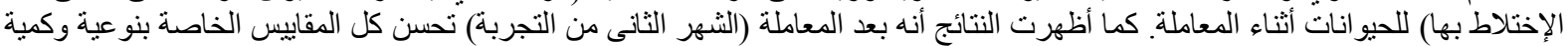

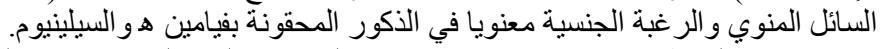

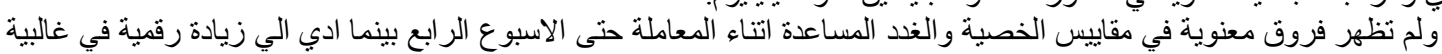

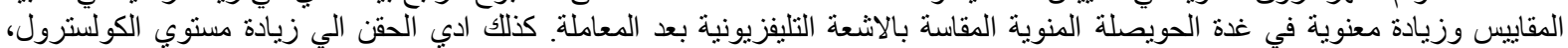

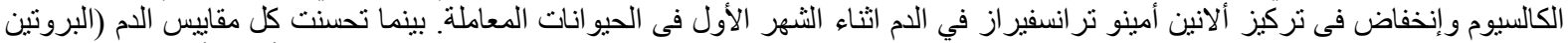

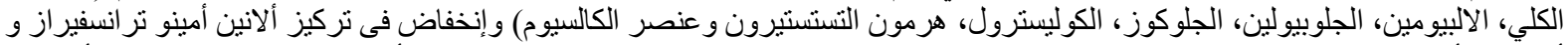

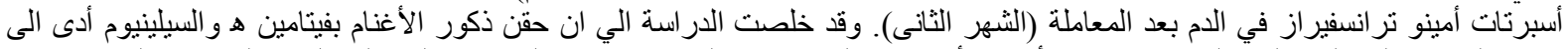

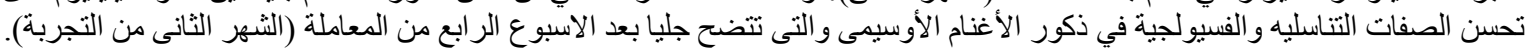

